\title{
Effects of Organic Acids Mix and Modified Atmosphere Packaging on the Storage Quality of Sliced Bacon
}

\author{
Muhlisin, Sun Moon Kang ${ }^{1}$, Won Hee Choi, Keun Taik Lee ${ }^{2}$, Sung Hee Cheong ${ }^{3}$, and Sung Ki Lee* \\ Department of Animal Products and Food Science, Kangwon National University, Chuncheon 200-701, Korea \\ ${ }^{I}$ National Institute of Animal Science, Rural Development Administration, Suwon 441-706, Korea \\ ${ }^{2}$ Department of Food Processing and Distribution, Gangneung-Wonju National University, Gangneung 210-702, Korea \\ ${ }^{3}$ Geo Food Tech Institute, Seongnam 463-741, Korea
}

\begin{abstract}
The effects of organic acids mix (0.4\%) and modified atmosphere packaging (MAP) on the storage quality of sliced bacon were investigated. Pork bellies were treated with or without organic acids at the curing stage. The organic acids mix comprised 35\% sodium acetate, $25 \%$ salt, $15 \%$ calcium lactate, $11 \%$ trisodium citrate, $7 \%$ ascorbate, and $7 \%$ citric acid. The cured pork bellies were smoked and packaged with $50 \% \mathrm{CO}_{2}+50 \% \mathrm{~N}_{2}\left(50 \% \mathrm{CO}_{2}-\mathrm{MAP}\right)$ and $100 \% \mathrm{~N}_{2}\left(100 \% \mathrm{~N}_{2}\right.$-MAP), and stored at $5^{\circ} \mathrm{C}$ for $14 \mathrm{~d}$. The $50 \% \mathrm{CO}_{2}$-MAP showed a higher $\mathrm{pH}$ value $(p<0.05)$ up to $10 \mathrm{~d}$, a lower protein deterioration $(p<0.05)$ as measured by volatile basic nitrogen $(\mathrm{VBN})$ from 6 to $14 \mathrm{~d}$, and a higher color value of lightness (CIE $\left.\mathrm{L}^{*}\right)$ compared to $100 \% \mathrm{~N}_{2}$-MAP. The development of lipid oxidation measured by thiobarbituric acid reactive substance (TBARS) values seemed to be effectively controlled throughout the storage period in both $50 \% \mathrm{CO}_{2}$-MAP and $100 \% \mathrm{~N}_{2}$-MAP regardless of the application of organic acids. The $50 \% \mathrm{CO}_{2}-\mathrm{MAP}$ inhibited the growth of aerobic and anaerobic bacteria $(p<0.05)$ both in non-added and bacon added with organic acids mix. The $50 \% \mathrm{CO}_{2}$-MAP alone seemed to be effective in delaying the growth of bacteria since the use of organic acids mix gave no additional effects. The addition of organic acids mix lowered the $\mathrm{pH}$ value $(p<0.05)$, effectively retarded the protein deterioration $(p<0.05)$, and showed a higher color value of lightness (CIE L*) value $(p<0.05)$ and lower color value of redness ( $\left.\mathrm{CIE} \mathrm{a}{ }^{*}\right)$ value $(p<0.05)$. In conclusion, $50 \% \mathrm{CO}_{2}$ MAP showed better quality and self-life of sliced bacon during storage. However, the beneficial effect of organic acids mix was not noticed in the concentration used in this experiment.
\end{abstract}

Key words: modified atmosphere packaging, organic acids mix, sliced bacon, storage quality

\section{Introduction}

Fresh pork belly (Samgyeopsal) is popular meat-based cuisine in Korea (Nam et al., 2010). Bacon is the cured meat product prepared from pork belly ( $\mathrm{Yi}$ and Chen, 2003). Recently, the meat industries in Korea have been trying to develop a new type of the pork belly-based products which is manufactured as a ready-to-cook product. Since this kind of products is not cooked, it can possess different quality and storage characteristics. Therefore, it is necessary to develop the packaging methods and the suitable preservatives in order to keep the quality of smoked pork belly (bacon) during storage and marketing.

\footnotetext{
*Corresponding author: Sung Ki Lee, Department of Animal Products and Food Science, Kangwon National University, Chuncheon 200-701, Korea. Tel: 82-33-250-8646, Fax: 82-33251-7719, E-mail: skilee@kangwon.ac.kr
}

Modified atmosphere packaging (MAP) has been used by meat industry to extend the shelf-life as well as to keep the quality characteristics of meat products. Usually, gases used in MAP are oxygen $\left(\mathrm{O}_{2}\right)$, carbon dioxide $\left(\mathrm{CO}_{2}\right)$, nitrogen $\left(\mathrm{N}_{2}\right)$, and other gases in small percentage such as, carbon monoxide (CO), etc. MAP is commonly divided into low oxygen and high oxygen MAP based on the oxygen contents. High $\mathrm{O}_{2}$ MAP may contain $25-90 \%$ $\mathrm{O}_{2}$ and $15-80 \% \mathrm{CO}_{2}$ (Blakistone, 1999), and the common composition of high $\mathrm{O}_{2}$ MAP is $80 \% \mathrm{O}_{2}: 20 \% \mathrm{CO}_{2}$ ( $\mathrm{Kim}$ et al., 2010; McMillin, 2008). High $\mathrm{O}_{2}$ MAP preserves the bright red color of meat (Jayasingh et al., 2002; Okayama et al., 1995), but due to the elevated oxidative conditions, this MAP promotes the lipid oxidation (Cayuela et al., 2004), and has negative effects on color and flavor stability (Grobbel et al., 2008; Kim et al., 2010; Zakrys et al., 2008). Premature browning during the cooking is another negative effect of high $\mathrm{O}_{2}$ MAP 
(John et al., 2005; Seyfert et al., 2004). Low oxygen MAP may contain less than $20 \%$ of $\mathrm{O}_{2}$ and the rest composition is composed of $\mathrm{CO}_{2}$ and $\mathrm{N}_{2} \cdot \mathrm{CO}_{2}$ is utilized in MAP gas composition because of its antibacterial effects, which are well documented by Jakobsen and Bertelsen (2000), McMillin (2008), and Renerre and Labadie (1993). In addition, Smith et al. (1990) suggested that 20$60 \%$ of $\mathrm{CO}_{2}$ in MAP is required to detain the growth of bacteria. Due to the absence of oxygen in low $\mathrm{O}_{2}$ MAP, the metmyoglobin (brown pigment) will be formed instead of oxymyoglobin (bright-red pigment) (Mancini and Hunt, 2005), and the meat color will appear darker and not attractive as like fresh meat. Sebranek and Houser (2006) noted that for cured meats, low oxygen MAP either with $100 \%$ nitrogen or carbon dioxide/nitrogen blends can be used for MAP applications.

Besides the packaging aspect using MAP, prolonging the shelf-life can be achieved by the addition of diverse preservatives to the meat and meat products. Cured meat products are characterized by the addition of nitrite and nitrate to the meat products, while other preservatives such as salts, like sodium chloride $(\mathrm{NaCl})$, ascorbic acid, and other organic acids were added (Sebranek and Bacus, 2007). Nitrite reactions are responsible on the characteristics of meat color, microbial inhibition, antioxidants effects and flavor of cured meat (Sebranek and Bacus, 2007). Salt has been used since ancient times as ingredient of processed meat products, because of its preservative properties by reducing the bacterial growth and improvement in flavor and texture (Desmond, 2006). Ascorbic acid is known as an effective antioxidant to inhibit color changes in meat (Lee at al., 1999; Sanchez-Escalante et al., 2001). Sodium salt, the salt form of the low molecular weight organic acids such as acetic acid, lactic acid and citric acid has been used to control the microbial growth and to improve the color stability, and shelf-life in meat (Maca et al., 1997; Sallam and Samejima, 2004; Shelef et al., 1997). Sallam (2007) studied that sodium acetate and sodium lactate delayed the lipid oxidation and microbial growth in sliced salmon. It was also reported that sodium acetate improved the color stability in pork (Livingston et al., 2004), and the combined use of sodium acetate with potassium lactate resulted in a synergistic effect on improving color stability in pork (Jensen et al., 2003). Calcium lactate is generally recognized as safe food ingredient, and is commonly used in meat industry (Daengprok et al., 2002), as an antibacterial agent (Shelef and Potluri, 1995). Preservatives combined with MAP may improve the antibacterial activity. Schirmer and Langsrud (2010) reported that citric acid and acetic acid in combinations with $\mathrm{CO}_{2}$ packaging inhibited bacterial growth in marinated pork meat. In addition, Schirmer et al. (2009) showed that the combination of preservatives and $\mathrm{CO}_{2}$-MAP prolonged the shelf-life of salmon without negative effects on sensory characteristics.

Previous studies have evaluated the effects of preservatives and $\mathrm{CO}_{2}$ in fresh pork (Schirmer and Langsrud, 2010), Hanwoo ground beef (Muhlisin et al., 2010), and salmon (Schirmer et al., 2009), but there is a dearth information on the effects of organic acids mix and $\mathrm{CO}_{2}$ on the bacon quality. Therefore, this study was conducted to investigate the effects of organic acids mix and organic acids salt on the storage quality of sliced bacon.

\section{Materials and Methods}

\section{Sample preparation}

The samples were prepared from pork belly (with thickness $5 \pm 1 \mathrm{~cm}$ ) by injecting the curing solution with formulation as described in Table 1. Frozen pork bellies were thawed at $2^{\circ} \mathrm{C}$ for $12 \mathrm{~h}$. The bellies were divided into two groups, one group was treated with $0.4 \%$ organic acids mix added in the curing solution, and the other was without addition of organic acid mix (non-added). After the injection of curing solution, the bacon was tumbled for $90 \mathrm{~min}$ at $10^{\circ} \mathrm{C}$, followed by curing for $24 \mathrm{~h}$ at $0^{\circ} \mathrm{C}$. The cured bellies (bacon) were smoked at $60^{\circ} \mathrm{C}$ for $15 \mathrm{~min}$ and cooled at $2^{\circ} \mathrm{C}$ for $12 \mathrm{~h}$. The bacon was then sliced

Table 1. Formulas of experimental sliced bacon

\begin{tabular}{lcc}
\hline \multirow{2}{*}{\multicolumn{1}{c}{ Ingredients }} & \multicolumn{2}{c}{ Concentration } \\
\cline { 2 - 3 } & Non-added & $\begin{array}{c}\text { Added with organic } \\
\text { acids mix }\end{array}$ \\
\hline Pork belly & 84.95 & 84.55 \\
Curing solution & 12.74 & 12.74 \\
Water & 0.85 & 0.85 \\
Salt & 0.01 & 0.01 \\
Sodium nitrite & 0.21 & 0.21 \\
Phosphates & 0.04 & 0.04 \\
Potassium erythorbate & 0.17 & 0.17 \\
L-glutamate & 0.85 & 0.85 \\
Sugar & 0.17 & 0.17 \\
White pepper & 0.01 & 0.01 \\
Allspice & 0.00 & 0.40 \\
Organic acids mix ${ }^{1)}$ & 100.00 & 100.00 \\
\hline \multicolumn{1}{c}{ Total } & &
\end{tabular}

${ }^{1)}$ This product is GF Bactostop (Product number: 1379) made by Pacovis Co. (Switzerland). It contains 25\% salt, $7 \%$ ascorbic acid, $35 \%$ sodium acetate, $15 \%$ calcium lactate, $11 \%$ tri-sodium citrate, and $7 \%$ citric acid, and its $\mathrm{pH}$ value is $5.5 \pm 0.5$. 
into $3 \pm 0.5 \mathrm{~mm}$ of thickness. Three slices of bacon were placed on the tray $\left(\max . \mathrm{O}_{2}\right.$ transmission rate $=0.1 \mathrm{cc} / 24$ $\mathrm{h} / \mathrm{cm}^{2}$ at $23^{\circ} \mathrm{C}, 0 \% \mathrm{RH}$; water vapor transmission rate $=$ $7.87 \mathrm{mg} / 24 \mathrm{~h} / \mathrm{cm}^{2}$ at $38^{\circ} \mathrm{C}, 100 \% \mathrm{RH}$, Cryovac Sealed Air Corp., USA) for the following packaging methods. The trays were sealed with $\mathrm{O}_{2}$ barrier film (max. $\mathrm{O}_{2}$ transmission rate $=0.39 \mathrm{cc} / 24 \mathrm{~h} / \mathrm{cm}^{2}$ at $4.4^{\circ} \mathrm{C}, 100 \% \mathrm{RH}$; Cryovac Sealed Air Corp., USA). The trays were filled with either $50 \% \mathrm{CO}_{2}+50 \% \mathrm{~N}_{2}\left(50 \% \mathrm{CO}_{2}\right.$-MAP) or $100 \% \mathrm{~N}_{2}(100 \%$ $\mathrm{N}_{2}$-MAP) using a modified atmosphere packaging machine (Hypervac, Korea) equipped with the gas mixture (MAP Mix 9001 ME, PBI Dansensor, Denmark). Carbon dioxide and nitrogen were obtained from a local gas supplier (Baeklyung Specialty Gas Co., Korea). Four treatments used in this research are 1) non-treated sliced bacon $+50 \%$ $\mathrm{CO}_{2}$-MAP, 2) non-treated sliced bacon $+100 \% \mathrm{~N}_{2}$-MAP, 3) sliced bacon added with organic acids mix $+50 \% \mathrm{CO}_{2}-$ MAP, and 4) sliced bacon added with organic acids mix ${ }^{+}$ $100 \% \mathrm{~N}_{2}$-MAP. All samples were stored at $5^{\circ} \mathrm{C}$ for $14 \mathrm{~d}$.

\section{The $\mathbf{p H}$ determination}

Ten grams of lean meat part of sliced bacon were added with $100 \mathrm{~mL}$ of distilled water and then homogenized at 10,000 rpm for $60 \mathrm{sec}$ using a homogenizer (PH91, SMT Co. Ltd., Japan). The $\mathrm{pH}$ value of the homogenized sample was measured using a $\mathrm{pH}$ meter (SevenEasy $\mathrm{pH}$, Mettler-Toledo $\mathrm{GmbH}$, Switzerland). Measurements were performed in every sample in triplicates.

\section{Thiobarbituric acid reactive substance (TBARS) value analysis}

The TBARS value was measured according to Sinhuber and Yu (1977). Briefly, $0.5 \mathrm{~g}$ of lean meat part of sliced bacon was mixed with 3 drops of antioxidants solution, $3 \mathrm{~mL}$ of thiobarbituric acid (TBA) solution, and 17 $\mathrm{mL}$ of $25 \%(\mathrm{w} / \mathrm{v}) \mathrm{TCA}$. The mixture was heated at $100^{\circ} \mathrm{C}$ for $30 \mathrm{~min}$ and then centrifuged at 3,500 rpm for $30 \mathrm{~min}$. An absorbance of supernatant was measured at $532 \mathrm{~nm}$ using a spectrophotometer (UV-mini-1240, Shimadzu, Japan). The result was calculated as mg malonaldehyde (MA) per $\mathrm{kg}$ of sample.

\section{Volatile basic nitrogen (VBN) value analysis}

The analysis of VBN value was performed according to Kohsaka (1975) method. Five grams of lean meat part of sliced bacon were homogenized with $30 \mathrm{~mL}$ of $5 \%(\mathrm{w} / \mathrm{v})$ TCA using a homogenizer (Ultra-Turrax T25 basic, Ika Werke GmbH \& Co., Germany) at 13,500 rpm for $2 \mathrm{~min}$. The homogenate was made up to $50 \mathrm{~mL}$ of final volume with $5 \%(\mathrm{w} / \mathrm{v})$ TCA and filtered using the Whatman filter paper No. 1. One $\mathrm{mL}$ of filtrate and $1 \mathrm{~mL}$ of borate buffer were placed in outer and inner of Conway dish, respectively, and then incubated at $37^{\circ} \mathrm{C}$ for $100 \mathrm{~min}$. Finally, the inner solution was titrated with $0.01 \mathrm{~N} \mathrm{HCl}$.

\section{Instrumental color measurement}

The surface color of the lean meat part of sliced bacon was monitored by measuring the CIE L* (lightness), CIE $\mathrm{a}^{*}$ (redness), and CIE b* (yellowness) using a color difference meter (CR-400, Konica Minolta Sensing Inc., Japan) and an illuminant $C$. The lean part of sliced bacon for instrumental color measurement was obtained by separation of lean layer and fat layer of bacon. All lean layers obtained from one pack were arranged so that wide surface was formed. The color instrument was calibrated using a white plate $\left(2^{\circ}\right.$ observer, CIE $L^{*}=97.46$, CIE $a^{*}=0.08$, CIE $\left.b^{*}=1.81\right)$. The color measurements were performed 10-15 times on each pack.

\section{Microbial analysis}

Ten grams of lean meat part of sliced bacon were placed into the autoclaved bag (Nasco Co., Ltd., USA) and added with $90 \mathrm{~mL}$ of $0.1 \%(\mathrm{w} / \mathrm{v})$ peptone solution. Each sample was homogenized using a Stomacher (Lab Blender 400, Seward Laboratory, UK) at medium speed for $2 \mathrm{~min}$. Serial 10-fold dilution was performed by mixing $1 \mathrm{~mL}$ of solution with $9 \mathrm{~mL}$ of $0.1 \%(\mathrm{w} / \mathrm{v})$ peptone solution. The plate count agars (Difco, USA) were used for aerobic and anaerobic bacterial counts. Agar plates were prepared according to the manufacturer's instruction. Samples were incubated for $48 \mathrm{~h}$ at $35^{\circ} \mathrm{C}$. Microbial populations were counted in 30 300 colonies and expressed as Log CFU per gram of sample.

\section{Statistical analysis}

All data were analyzed using SPSS 14.0 for Windows Evaluation Version (2005). The data was analyzed by one way analysis of variance, with treatments (packaging method and organic acid salts combination) as variable. Means of data in every day of storage were compared using Duncan's multiple range tests with examination for significant differences $(p<0.05)$.

\section{Results and Discussion}

\section{The $\mathrm{pH}$ value}

The $\mathrm{pH}$ value of non-added sliced bacon packed with $50 \% \mathrm{CO}_{2}$-MAP was higher $(p<0.05)$ than $\mathrm{pH}$ value of 
Table 2. Effects of organic acids mix and modified atmosphere packaging on the pH value, TBARS, and VBN of sliced bacon during storage at $5^{\circ} \mathrm{C}$

\begin{tabular}{|c|c|c|c|c|c|}
\hline \multirow{3}{*}{ Parameters } & \multirow{3}{*}{$\begin{array}{l}\text { Storage time } \\
\text { (d) }\end{array}$} & \multicolumn{4}{|c|}{ Treatments } \\
\hline & & \multicolumn{2}{|c|}{$50 \% \mathrm{CO}_{2}-\mathrm{MAP}$} & \multicolumn{2}{|c|}{$100 \% \mathrm{~N}_{2}-\mathrm{MAP}$} \\
\hline & & Non-added $^{1)}$ & Org. acids $\operatorname{mix}^{2}$ & Non-added & Org. acids mix \\
\hline \multirow{7}{*}{$\mathrm{pH}$} & 0 & $6.23 \pm 0.03^{\mathrm{aC}}$ & $6.22 \pm 0.01^{\mathrm{aB}}$ & $6.23 \pm 0.03^{\mathrm{aB}}$ & $6.22 \pm 0.01^{\mathrm{aA}}$ \\
\hline & 2 & $6.45 \pm 0.10^{\mathrm{aB}}$ & $6.34 \pm 0.02^{\mathrm{abA}}$ & $6.30 \pm 0.06^{\mathrm{bB}}$ & $5.96 \pm 0.04^{\mathrm{cB}}$ \\
\hline & 4 & $6.65 \pm 0.03^{\mathrm{aA}}$ & $6.33 \pm 0.10^{\mathrm{bA}}$ & $6.40 \pm 0.10^{\mathrm{bAB}}$ & $6.12 \pm 0.03^{\mathrm{cA}}$ \\
\hline & 6 & $6.51 \pm 0.06^{\mathrm{aA}}$ & $6.38 \pm 0.08^{\mathrm{bA}}$ & $6.53 \pm 0.06^{\mathrm{aA}}$ & $6.24 \pm 0.18^{\mathrm{bA}}$ \\
\hline & 8 & $6.62 \pm 0.04^{\mathrm{aA}}$ & $6.12 \pm 0.04^{\mathrm{cC}}$ & $6.36 \pm 0.08^{\mathrm{bAB}}$ & $6.03 \pm 0.02^{\mathrm{cB}}$ \\
\hline & 10 & $6.65 \pm 0.09^{\mathrm{aA}}$ & $6.18 \pm 0.09^{\mathrm{bBC}}$ & $6.55 \pm 0.13^{\mathrm{aA}}$ & $6.15 \pm 0.01^{\mathrm{bAB}}$ \\
\hline & 14 & $6.28 \pm 0.06^{\mathrm{bC}}$ & $6.12 \pm 0.03^{\mathrm{bC}}$ & $6.60 \pm 0.09^{\mathrm{aA}}$ & $6.19 \pm 0.11^{\mathrm{bA}}$ \\
\hline \multirow{7}{*}{$\begin{array}{c}\mathrm{TBARS}^{3)} \\
\text { (mg MA } \\
\text { /kg sample) }\end{array}$} & 0 & $0.18 \pm 0.05^{\mathrm{aA}}$ & $0.18 \pm 0.02^{\mathrm{aA}}$ & $0.18 \pm 0.05^{\mathrm{aA}}$ & $0.18 \pm 0.02^{\mathrm{aA}}$ \\
\hline & 2 & $0.21 \pm 0.05^{\mathrm{aA}}$ & $0.19 \pm 0.01^{\mathrm{aA}}$ & $0.19 \pm 0.03^{\mathrm{aA}}$ & $0.19 \pm 0.05^{\mathrm{aA}}$ \\
\hline & 4 & $0.15 \pm 0.03^{\mathrm{aA}}$ & $0.18 \pm 0.04^{\mathrm{aA}}$ & $0.17 \pm 0.02^{\mathrm{aA}}$ & $0.19 \pm 0.05^{\mathrm{aA}}$ \\
\hline & 6 & $0.12 \pm 0.03^{\mathrm{aA}}$ & $0.17 \pm 0.03^{\mathrm{aA}}$ & $0.16 \pm 0.04^{\mathrm{aA}}$ & $0.15 \pm 0.06^{\mathrm{aA}}$ \\
\hline & 8 & $0.18 \pm 0.03^{\mathrm{aA}}$ & $0.19 \pm 0.05^{\mathrm{aA}}$ & $0.17 \pm 0.04^{\mathrm{aA}}$ & $0.20 \pm 0.04^{\mathrm{aA}}$ \\
\hline & 10 & $0.17 \pm 0.03^{\mathrm{aA}}$ & $0.16 \pm 0.06^{\mathrm{aA}}$ & $0.16 \pm 0.02^{\mathrm{aA}}$ & $0.18 \pm 0.04^{\mathrm{aA}}$ \\
\hline & 14 & $0.18 \pm 0.05^{\mathrm{aA}}$ & $0.15 \pm 0.03^{\mathrm{aA}}$ & $0.24 \pm 0.03^{\mathrm{aA}}$ & $0.17 \pm 0.03^{\mathrm{aA}}$ \\
\hline \multirow{7}{*}{$\begin{array}{l}\left.\mathrm{VBN}^{4}\right) \\
(\mathrm{mg} \%)\end{array}$} & 0 & $12.77 \pm 0.71^{\mathrm{aD}}$ & $11.41 \pm 0.27^{\mathrm{bC}}$ & $12.77 \pm 0.71^{\mathrm{aD}}$ & $11.41 \pm 0.27^{\mathrm{bE}}$ \\
\hline & 2 & $13.54 \pm 0.49^{\mathrm{aCD}}$ & $11.60 \pm 0.47^{\mathrm{bC}}$ & $13.31 \pm 0.55^{\mathrm{aCD}}$ & $11.41 \pm 0.50^{\mathrm{bE}}$ \\
\hline & 4 & $13.77 \pm 0.40^{\mathrm{aC}}$ & $12.19 \pm 1.07^{\mathrm{bC}}$ & $13.91 \pm 0.33^{\mathrm{aC}}$ & $12.95 \pm 0.54^{\mathrm{bD}}$ \\
\hline & 6 & $13.22 \pm 0.23^{\mathrm{bCD}}$ & $11.59 \pm 0.60^{\mathrm{cC}}$ & $13.70 \pm 0.87^{\mathrm{abC}}$ & $14.32 \pm 0.56^{\mathrm{aC}}$ \\
\hline & 8 & $15.23 \pm 0.54^{\mathrm{bB}}$ & $13.46 \pm 0.45^{\mathrm{dB}}$ & $17.11 \pm 0.33^{\mathrm{aB}}$ & $14.19 \pm 0.29^{\mathrm{cC}}$ \\
\hline & 10 & $14.92 \pm 1.00^{\mathrm{bB}}$ & $13.79 \pm 0.42^{\mathrm{cB}}$ & $17.10 \pm 0.56^{\mathrm{aB}}$ & $16.92 \pm 0.52^{\mathrm{aB}}$ \\
\hline & 14 & $17.24 \pm 0.96^{\mathrm{bcA}}$ & $16.52 \pm 0.50^{\mathrm{cA}}$ & $18.33 \pm 0.34^{\mathrm{aA}}$ & $17.97 \pm 0.67^{\mathrm{abA}}$ \\
\hline
\end{tabular}

${ }^{\mathrm{a}-\mathrm{d}}$ Values (Means $\left.\pm \mathrm{SD}\right)$ with different superscripts in the same row differ significantly $(p<0.05)$.

${ }^{\text {A-E}}$ Values (Means $\pm \mathrm{SD}$ ) with different superscripts in the same column differ significantly $(p<0.05)$.

${ }^{1)}$ Non-added : The bacons were treated with curing solution without addition of organic acids mix.

${ }^{2}$ Organic acids mix : The bacons were treated with curing solution with organic acids mix (contained 25\% salt, $7 \%$ ascorbic acid, $35 \%$ sodium acetate, $15 \%$ calcium lactate, $11 \%$ tri-sodium citrate, and $7 \%$ citric acid), respectively.

${ }^{3)}$ Thiobarbituric acid reactive substances

${ }^{4)}$ Volatile basic nitrogen

non-added group with $100 \% \mathrm{~N}_{2}$-MAP at 2,4 and $8 \mathrm{~d}$ of storage (Table 2). The $\mathrm{pH}$ value of sliced bacon treated with organic acids mix and packed with $100 \% \mathrm{~N}_{2}$-MAP was the lowest at 2, 4 and $8 \mathrm{~d}$ of storage. Different results have been reported by Rubio et al. (2007) in which there were no effect of different composition of $\mathrm{CO}_{2}$ on $\mathrm{pH}$ value of dry cured beef. In addition, Viana et al. (2005) also reported that MAP did not show strong variation in $\mathrm{pH}$ of fresh pork loin. However, the addition of organic acids significantly lowered $(p<0.05)$ the $\mathrm{pH}$ value of sliced bacon compared to the non-added groups both in $50 \% \mathrm{CO}_{2}$-MAP and $100 \% \mathrm{~N}_{2}$-MAP. The lower $\mathrm{pH}$ value in sliced bacon treated with organic acid might be due to the acid form of organic acids mix. According to the product information, the $\mathrm{pH}$ value of organic acids mix is $5.5 \pm 0.5$. The lowering effect of $\mathrm{pH}$ by the addition of organic acids mix was also reported by previous studies. For instance, Aran (2001) showed the decreasing pH value of beef from 6.0 to 5.5 due to the addition of $3 \%$ calcium lactate; Kim et al. (2009) reported the lower $\mathrm{pH}$ due to calcium lactate enhancement in beef steaks and Velugoti et al. (2007) reported the decreased $\mathrm{pH}$ level in pork by increasing the concentration of calcium lactate.

\section{TBARS value}

Lipid oxidation causes rancidity (off-flavor and off-odor) in meat (Jakobsen and Bertelsen, 2000), and TBARS is a strong objective predictor of the rancidity perception of meat and meat products (McMillin, 2008). Skibsted et al. (1998) mentioned the factors affecting the lipid oxidation, like oxygen concentration, lighting, temperature, the presence of pro- and antioxidant, the saturation degree of fatty acids, and the presence of enzymes. The TBARS levels were around 0.15 to $0.24 \mathrm{mg} \mathrm{MA} / \mathrm{kg}$ sample (Table 2). For comparison, Lin and Lin (2002) reported the TBARS value of Chinese-style sausage added with sodium lactate 
and trisodium phosphate were less than $0.5 \mathrm{mg} \mathrm{MA} / \mathrm{kg}$ sample. No differences were found in TBARS value ( $p>$ 0.05 ) due to the effects of gas composition of MAP. The addition of organic acids mix also gave no effects on TBARS value during the storage. Lin and Chuang (1999) reported no differences in TBARS value because of organic acids addition in low-fat Chinese sausage. In addition Brewer et al. (1991) also found no effect of different level of organic acids on TBARS value of fresh pork sausage.

\section{Volatile basic nitrogen (VBN)}

The protein deterioration, represented as VBN of sliced bacon during storage is showed in Table 2. VBN value increased with the increase of storage days. Arashihar et al. (2004) reported that VBN increased with the increasing of storage time in Air-P, vacuum and MAP of rainbow trout (Oncorynchus mykiss) fillets. The using of 50\% $\mathrm{CO}_{2}$-MAP significantly detained the protein deterioration $(p<0.05)$ both in the non-added and group added with organic acids mix, from $6 \mathrm{~d}$ to $14 \mathrm{~d}$ of storage. The lower VBN formation may be related with the lower bacterial counts of sliced bacon under $50 \% \mathrm{CO}_{2}$-MAP compared to $100 \% \mathrm{~N}_{2}$-MAP (Table 5). Protein deterioration (represented by VBN value) is associated with the activity of amino acid decarboxylase of microorganisms (Lin and Lin, 2002). The addition of organic acids mix detained the protein deterioration in $50 \% \mathrm{CO}_{2}$-MAP during the storage, while in $100 \% \mathrm{~N}_{2}$-MAP the detaining effect of organic acids on the protein deterioration only can be shown at $0,2,4$ and $8 \mathrm{~d}$ of storage. The combination of organic acids mix and $50 \% \mathrm{CO}_{2}$-MAP showed the lowest VBN value compared to other treatments. Similar results were also reported by Lin and Lin (2002) that the addition of organic acids mix lowered the VBN value of lowfat Chinese style sausage. Little information about the protein deterioration (VBN) of bacon is available. Therefore, the detaining effects of organic acids mix on protein deterioration must be useful for further studies.

\section{Instrumental color}

The CIE L* value (lightness) is presented in Table 3. The CIE L* value of lean meat of sliced bacon under $50 \% \mathrm{CO}_{2}$-MAP fluctuated during storage. The CIE $\mathrm{L}^{*}$ value of lean meat of non-added sliced bacon under $50 \%$

Table 3. Effects of organic acids mix and modified atmosphere packaging on the instrumental color of sliced bacon during storage at $5^{\circ} \mathrm{C}$

\begin{tabular}{|c|c|c|c|c|c|}
\hline \multirow{3}{*}{$\begin{array}{c}\text { Color } \\
\text { Parameters }\end{array}$} & \multirow{3}{*}{$\begin{array}{l}\text { Storage time } \\
\text { (d) }\end{array}$} & \multicolumn{4}{|c|}{ Treatments } \\
\hline & & \multicolumn{2}{|c|}{$50 \% \mathrm{CO}_{2}$-MAP } & \multicolumn{2}{|c|}{$100 \% \mathrm{~N}_{2}$-MAP } \\
\hline & & Non-added & Org. acid mix & Non-added & Org. acid mix \\
\hline \multirow{7}{*}{$\begin{array}{c}\text { CIE L* } \\
\text { (Lightness) }\end{array}$} & 0 & $49.80 \pm 2.47^{\mathrm{aB}}$ & $48.87 \pm 4.03^{\mathrm{aD}}$ & $49.81 \pm 2.47^{\mathrm{aB}}$ & $48.87 \pm 4.03^{\mathrm{aD}}$ \\
\hline & 2 & $51.16 \pm 3.94^{\mathrm{bA}}$ & $52.52 \pm 4.74^{\mathrm{aA}}$ & $52.03 \pm 3.21^{\mathrm{abA}}$ & $52.05 \pm 2.90^{\mathrm{abA}}$ \\
\hline & 4 & $50.79 \pm 3.17^{\mathrm{bAB}}$ & $52.46 \pm 3.05^{\mathrm{aA}}$ & $49.23 \pm 3.39^{\mathrm{cB}}$ & $50.18 \pm 3.64^{\mathrm{bcBC}}$ \\
\hline & 6 & $51.62 \pm 3.56^{\mathrm{aA}}$ & $48.83 \pm 3.22^{\mathrm{bcD}}$ & $48.15 \pm 4.04^{\mathrm{cC}}$ & $49.49 \pm 3.94^{\mathrm{bCD}}$ \\
\hline & 8 & $49.49 \pm 2.44^{\mathrm{bB}}$ & $50.73 \pm 3.48^{\mathrm{aBC}}$ & $49.08 \pm 3.33^{\mathrm{bBC}}$ & $50.54 \pm 3.46^{\mathrm{aBC}}$ \\
\hline & 10 & $50.84 \pm 3.44^{\mathrm{aAB}}$ & $51.38 \pm 3.28^{\mathrm{aAB}}$ & $49.26 \pm 3.57^{\mathrm{bB}}$ & $50.72 \pm 2.77^{\mathrm{aB}}$ \\
\hline & 14 & $48.66 \pm 3.12^{\mathrm{bC}}$ & $49.96 \pm 3.42^{\mathrm{aCD}}$ & $48.12 \pm 2.99^{\mathrm{bC}}$ & $49.59 \pm 2.88^{\mathrm{aCD}}$ \\
\hline \multirow{7}{*}{$\begin{array}{c}\text { CIE a* } \\
\text { (Redness) }\end{array}$} & 0 & $9.58 \pm 1.50^{\mathrm{bE}}$ & $11.74 \pm 1.87^{\mathrm{aE}}$ & $9.58 \pm 1.50^{\mathrm{bD}}$ & $11.74 \pm 1.87^{\mathrm{aC}}$ \\
\hline & 2 & $15.35 \pm 2.41^{\mathrm{bD}}$ & $16.42 \pm 2.72^{\mathrm{aAB}}$ & $15.24 \pm 2.52^{\mathrm{bC}}$ & $16.61 \pm 1.98^{\mathrm{aA}}$ \\
\hline & 4 & $16.64 \pm 2.20^{\mathrm{aB}}$ & $16.67 \pm 2.02^{\mathrm{aA}}$ & $15.92 \pm 2.28^{\mathrm{bC}}$ & $16.71 \pm 2.34^{\mathrm{aA}}$ \\
\hline & 6 & $16.77 \pm 2.52^{\mathrm{aB}}$ & $15.94 \pm 2.00^{\mathrm{bBC}}$ & $16.71 \pm 2.62^{\mathrm{aB}}$ & $15.32 \pm 2.83^{\mathrm{bB}}$ \\
\hline & 8 & $17.74 \pm 1.85^{\mathrm{aA}}$ & $14.85 \pm 2.21^{\mathrm{cD}}$ & $17.68 \pm 2.55^{\mathrm{aA}}$ & $16.82 \pm 2.34^{\mathrm{bA}}$ \\
\hline & 10 & $17.69 \pm 2.48^{\mathrm{aA}}$ & $14.60 \pm 1.97^{\mathrm{cD}}$ & $17.27 \pm 2.19^{\mathrm{abAB}}$ & $16.82 \pm 2.31^{\mathrm{bA}}$ \\
\hline & 14 & $17.39 \pm 2.14^{\mathrm{aA}}$ & $15.62 \pm 2.01^{\mathrm{cC}}$ & $17.62 \pm 2.28^{\mathrm{aA}}$ & $16.41 \pm 1.87^{\mathrm{bA}}$ \\
\hline \multirow{7}{*}{$\begin{array}{c}\text { CIE b* } \\
\text { (Yellowness) }\end{array}$} & 0 & $6.39 \pm 1.09^{\mathrm{bE}}$ & $6.94 \pm 1.24^{\mathrm{aB}}$ & $6.39 \pm 1.09^{\mathrm{bD}}$ & $6.94 \pm 1.24^{\mathrm{aD}}$ \\
\hline & 2 & $9.47 \pm 1.28^{\mathrm{aD}}$ & $9.57 \pm 1.38^{\mathrm{aA}}$ & $9.91 \pm 1.47^{\mathrm{aB}}$ & $8.91 \pm 1.61^{\mathrm{bC}}$ \\
\hline & 4 & $9.98 \pm 1.58^{\mathrm{aBC}}$ & $9.57 \pm 1.47^{\mathrm{bA}}$ & $9.27 \pm 1.34^{\mathrm{bC}}$ & $9.30 \pm 1.42^{\mathrm{bBC}}$ \\
\hline & 6 & $9.63 \pm 1.64^{\mathrm{aCD}}$ & $9.69 \pm 1.31^{\mathrm{aA}}$ & $9.94 \pm 1.31^{\mathrm{aB}}$ & $8.99 \pm 1.77^{\mathrm{bC}}$ \\
\hline & 8 & $10.38 \pm 1.59^{\mathrm{aB}}$ & $9.44 \pm 1.47^{\mathrm{cA}}$ & $10.07 \pm 1.29^{\mathrm{abAB}}$ & $9.88 \pm 1.19^{\mathrm{bA}}$ \\
\hline & 10 & $11.17 \pm 1.65^{\mathrm{aA}}$ & $9.07 \pm 1.55^{\mathrm{dA}}$ & $10.25 \pm 1.10^{\mathrm{bAB}}$ & $9.60 \pm 1.50^{\mathrm{cAB}}$ \\
\hline & 14 & $9.17 \pm 1.22^{\mathrm{cD}}$ & $9.15 \pm 1.42^{\mathrm{cA}}$ & $10.37 \pm 1.14^{\mathrm{aA}}$ & $9.65 \pm 1.37^{\mathrm{bAB}}$ \\
\hline
\end{tabular}

${ }^{\text {a-c }}$ Values (Means \pm SD) with different superscripts in the same row differ significantly $(p<0.05)$.

${ }^{\mathrm{A}-\mathrm{E}}$ Values (Means $\left.\pm \mathrm{SD}\right)$ with different superscripts in the same column differ significantly $(p<0.05)$. 
$\mathrm{CO}_{2}$-MAP was higher $(p<0.05)$ than control group under $100 \% \mathrm{~N}_{2}$-MAP at 4,6 , and $10 \mathrm{~d}$ of storage. The addition of organic acids increased $(p<0.05)$ the CIE L* value of lean meat of sliced bacon packaged with $50 \% \mathrm{CO}_{2}$-MAP at $2,4,8$, and $14 \mathrm{~d}$, while in $100 \% \mathrm{~N}_{2}$-MAP the addition of organic acids mix increased the CIE L* value from 6 to $14 \mathrm{~d}$. Arganosa and Marriot (1989) reported similar results, that $\mathrm{CIE} \mathrm{L}^{*}$ value of beef with organic acids mix addition was higher compared to the non-treated beef. Other previous studies also showed the lightening ability of organic acids (Knock et al., 2006; Lawrence et al., 2003), but different with Maca et al. (1999), and Mancini et al. (2005) who found darkening effect of organic acids in various meat commodities. The combination of $50 \%$ $\mathrm{CO}_{2}$-MAP and organic acids showed the highest $(p<0.05)$ CIE $\mathrm{L}^{*}$ value on $4 \mathrm{~d}$.

The CIE $\mathrm{a}^{*}$ value (redness) of lean meat of non-added sliced bacon under 50\% $\mathrm{CO}_{2}$-MAP and 100\% $\mathrm{N}_{2}$-MAP increased until $6 \mathrm{~d}$ of storage and slightly decreased from 8 to $4 \mathrm{~d}$ (Table 3). Generally, no difference was found in the CIE a* value of lean meat color of control sliced bacon packaged with 50\% $\mathrm{CO}_{2}$-MAP and $100 \% \mathrm{~N}_{2}$-MAP. The addition of organic acids resulted in more red $(p<0.05)$ color of lean meat of sliced bacon (higher CIE a* value) only at the beginning of storage ( 0 and $2 \mathrm{~d}$ in $50 \% \mathrm{CO}_{2}$ MAP and 0 to $4 \mathrm{~d}$ in $100 \% \mathrm{~N}_{2}$-MAP). The CIE a* value of lean meat of sliced bacon treated with organic acids mix was lower $(p<0.05)$ than the control from $6 \mathrm{~d}$ until the end of storage time both in 50\% $\mathrm{CO}_{2}$-MAP and $100 \%$ $\mathrm{N}_{2}$-MAP. Significant loss of redness was reported by Shrestha and Ming (2006) on fresh pork due to the effects of lactic acids. Similar results were reported by Arganosa and Marriott (1989) on beef treated with organic acids mix; in pork loin by Hayes et al. (2005), and Jensen et al. (2003) on enhanced pork chops treated with phosphate. Arganosa and Marriott (1989) noted lower CIE a* values on the meat with lower $\mathrm{pH}$ values. This statement is in accordance with our $\mathrm{pH}$ data in which $\mathrm{pH}$ value of bacon treated with organic acids mix also was lower. The combination of $50 \% \mathrm{CO}_{2}$-MAP and organic acids showed the lowest CIE $\mathrm{a}^{*}$ value from $8 \mathrm{~d}$ to the end of storage time $(p<0.05)$. The addition of organic acids mix resulted in lower CIE $b^{*}$ value of lean meat of sliced bacon in $50 \%$ $\mathrm{CO}_{2}$-MAP at 4, 8, and $10 \mathrm{~d}$ of storage, and at 2, 6, 10, and $14 \mathrm{~d}$ of storage in $100 \% \mathrm{~N}_{2}$-MAP.

\section{Microbial changes}

The aerobic bacterial counts of sliced bacon were increase in all the treatments after $2 \mathrm{~d}$ of storage (Table 4 ). In the non-added group, 50\% $\mathrm{CO}_{2}$-MAP delayed the growth of aerobic bacteria from 2 to $10 \mathrm{~d}$ of storage $(p<0.05)$ compared to $100 \% \mathrm{~N}_{2}$-MAP. The survival and the growth of pathogenic microorganism are affected by MAP (Blakistone, 1999). Carbon dioxide is well known as the antimicrobial gas used in MAP. The antimicrobial activity of $\mathrm{CO}_{2}$ was reported by Jacobsen and Bertelsen

Table 4. Effects of organic acids mix and modified atmosphere packaging on the aerobic and anaerobic bacterial population of sliced bacon during storage at $5^{\circ} \mathrm{C}$

(Unit: Log CFU/g sample)

\begin{tabular}{|c|c|c|c|c|c|}
\hline \multirow{3}{*}{ Microorganism } & \multirow{3}{*}{$\begin{array}{l}\text { Storage time } \\
\text { (d) }\end{array}$} & \multicolumn{4}{|c|}{ Treatments } \\
\hline & & \multicolumn{2}{|c|}{$50 \% \mathrm{CO}_{2}-\mathrm{MAP}$} & \multicolumn{2}{|c|}{$100 \% \mathrm{~N}_{2}$-MAP } \\
\hline & & Non-added & Org. acids mix & Non-added & Org. acids mix \\
\hline \multirow{6}{*}{ Aerobic bacteria } & 0 & $4.52 \pm 0.28^{\mathrm{aD}}$ & $3.70 \pm 0.06^{\mathrm{bD}}$ & $4.59 \pm 0.22^{\mathrm{aE}}$ & $3.48 \pm 0.20^{\mathrm{bD}}$ \\
\hline & 2 & $3.80 \pm 0.48^{\mathrm{bE}}$ & $4.23 \pm 0.51^{\mathrm{abCD}}$ & $4.27 \pm 0.43^{\mathrm{aE}}$ & $4.12 \pm 0.18^{\mathrm{abC}}$ \\
\hline & 4 & $4.99 \pm 0.30^{\mathrm{cD}}$ & $5.33 \pm 0.59^{\mathrm{bcB}}$ & $6.35 \pm 0.35^{\mathrm{aD}}$ & $5.74 \pm 0.65^{\mathrm{abB}}$ \\
\hline & 8 & $5.90 \pm 0.34^{\mathrm{bC}}$ & $5.46 \pm 0.20^{\mathrm{bB}}$ & $6.90 \pm 0.28^{\mathrm{aC}}$ & $5.89 \pm 0.76^{\mathrm{bB}}$ \\
\hline & 10 & $6.80 \pm 0.71^{\mathrm{cB}}$ & $7.69 \pm 0.21^{\mathrm{bA}}$ & $8.11 \pm 0.30^{\mathrm{aA}}$ & $7.91 \pm 0.28^{\mathrm{bA}}$ \\
\hline & 14 & $7.44 \pm 0.13^{\mathrm{aA}}$ & $7.21 \pm 0.39^{\mathrm{aA}}$ & $7.57 \pm 0.28^{\mathrm{aB}}$ & $7.33 \pm 0.21^{\mathrm{aA}}$ \\
\hline \multirow{6}{*}{ Anaerobic bacteria } & 0 & $5.02 \pm 0.61^{\mathrm{aD}}$ & $4.28 \pm 0.64^{\mathrm{aE}}$ & $5.02 \pm 0.61^{\mathrm{aC}}$ & $4.28 \pm 0.64^{\mathrm{aD}}$ \\
\hline & 2 & $4.04 \pm 0.56^{\mathrm{aE}}$ & $4.41 \pm 0.76^{\mathrm{aDE}}$ & $4.56 \pm 0.65^{\mathrm{aC}}$ & $4.40 \pm 0.58^{\mathrm{aD}}$ \\
\hline & 4 & $5.68 \pm 0.53^{\mathrm{bC}}$ & $5.57 \pm 0.75^{\mathrm{bC}}$ & $6.54 \pm 0.30^{\mathrm{aB}}$ & $6.18 \pm 0.51^{\mathrm{abC}}$ \\
\hline & 8 & $5.77 \pm 0.23^{\mathrm{bcC}}$ & $5.51 \pm 0.20^{\mathrm{cC}}$ & $6.84 \pm 0.27^{\mathrm{aB}}$ & $5.97 \pm 0.51^{\mathrm{bC}}$ \\
\hline & 10 & $6.78 \pm 0.75^{\mathrm{bB}}$ & $7.65 \pm 0.02^{\mathrm{abB}}$ & $8.56 \pm 0.49^{\mathrm{aA}}$ & $7.78 \pm 0.28^{\mathrm{aB}}$ \\
\hline & 14 & $8.13 \pm 0.26^{\mathrm{bA}}$ & $8.46 \pm 0.46^{\mathrm{abA}}$ & $8.92 \pm 0.26^{\mathrm{aA}}$ & $9.01 \pm 0.44^{\mathrm{aA}}$ \\
\hline
\end{tabular}

\footnotetext{
${ }^{\mathrm{a}-\mathrm{c}}$ Values (Means $\left.\pm \mathrm{SD}\right)$ with different superscripts in the same row differ significantly $(p<0.05)$.

${ }^{\mathrm{A}-\mathrm{E}}$ Values (Means $\pm \mathrm{SD}$ ) with different superscripts in the same column differ significantly $(p<0.05)$.
} 
(2000) in fresh beef; and McMillin (2008) in several meat products. Moreover, Schirmer and Langsrud (2010) found that $50 \% \mathrm{CO}_{2}$-MAP resulted in greater antimicrobial activity when it was combined with organic acids mix during the storage. These results are slightly different with ours, in which the antibacterial effects of organic acids mix were found at $0 \mathrm{~d}$ and $10 \mathrm{~d}$ in $50 \% \mathrm{CO}_{2}$-MAP and at 0,6 and $10 \mathrm{~d}$ of storage in $100 \% \mathrm{~N}_{2}$-MAP. At the end of storage, no differences were found in aerobic bacterial counts among the treatments. The anaerobic bacterial count showed similar trends with aerobic bacteria. In the nonadded group, the $50 \% \mathrm{CO}_{2}$-MAP showed lower anaerobic bacterial counts compared to $100 \% \mathrm{~N}_{2}$-MAP from 4 to $14 \mathrm{~d}(p<0.05)$. The addition of organic acids showed no effects on anaerobic bacterial counts both in $50 \%$ $\mathrm{CO}_{2}$-MAP and $100 \% \mathrm{~N}_{2}$-MAP. In other words, $50 \% \mathrm{CO}_{2}-$ MAP alone is enough to detain the anaerobic bacterial growth. It is well known that $\mathrm{CO}_{2}$ prolonged the shelf-life by inhibiting microbial growth (Gill and Tan, 1980; Wimpfheimer et al., 1990). In addition, Schirmer et al. (2009) showed that the combination of organic acid and $\mathrm{CO}_{2}$ packaging prolonged the shelf-life.

\section{Acknowledgement}

This research was supported by Technology Development Program for Agriculture and Forestry (108061-032-HD120), Ministry for Food, Agriculture, Forestry and Fisheries, Republic of Korea.

\section{References}

1. Aran, N. (2001) The effects of calcium and sodium lactates on growth from spores of Bacillus cereus and Clostridium perfringens in a 'sous-vide' beef goulash under temperature abuse. Int. J. Food Microbiol. 63, 117-123.

2. Arashihar, X., Hisar, O., Kaya, M., and Yanik, T. (2004) Effects of modified atmosphere and vacuum packaging on microbiological and chemical properties of rainbow trout (Oncorynchus mykiss) fillets. Int. J. Food Microbiol. 97, 209-214.

3. Arganosa, G. C. and Marriott, N. G. (1989) Organic acids as tenderizers of collagen in restructured beef. J. Food Sci. 54, 1173-1176.

4. Blakistone, B. A. (1999) Meats and poultry. In: Principles and applications of modified atmosphere packaging of foods. Blakistone, B. A. (ed) Aspen Publisher, Maryland, pp. 240290.

5. Brewer, M. S., McKeith, F., Martin, S. E., Dallmier, A. W., and Meyer, J. (1991) Sodium lactate effects on shelf-life, sensory, and physical characteristics of pork sausage. $J$.
Food Sci. 56, 1176-1178.

6. Cayuela, J. M., Gil, M. D., Banon, S., and Garrido, M. D. (2004) Effect of vacuum and modified atmosphere packaging on the quality of pork loin. Eur. Food Res. Technol. 219, 316-320.

7. Daengprok, W., Garnjanagoonchorn, W., and Mine, Y. (2002) Fermented pork sausage fortified with commercial or hen eggshell calcium lactate. Meat Sci. 62, 199-204.

8. Desmond, E. (2006) Reducing salt: A challenge for meat industry. Meat Sci. 74, 188-196.

9. Gill, C. O. and Tan, K. H. (1980) Effect of carbon dioxide on growth of meat spoilage bacteria. Appl. Environ. Microbiol. 39, 317-319.

10. Grobbel, J. P., Dikeman, M. E., Hunt, M. C., and Milliken, G. A. (2008) Effects of different packaging atmosphere and injection-enhancement on beef tenderness, sensory attributes, desmin degradation, and display color. J. Anim. Sci. 86, 26972710.

11. Hayes, J. E., Desmond, E. M., Troy, D. J., Buckley, D. J., and Mehra, R. (2005) The effect of enhancement with salt, phosphate and milk proteins on the physical and sensory properties of pork loin. Meat Sci. 72, 380-386.

12. Jakobsen, M. and Bertelsen, G. (2000) Color stability and lipid oxidation of fresh beef. Development of a response surface model for predicting the effects of temperature, storage time, and modified atmosphere composition. Meat Sci. 54, 49-57.

13. Jayasingh, P., Cornforth, D. P., Brennand, C. P., Carpenter, C. E., and Whittier, D. R. (2002) Sensory evaluation of ground beef stored in high-oxygen modified atmosphere. J. Food Sci. 67, 3493-3496.

14. Jensen, J. M., Prestat, C., Ryan, K. J., Robbins, K. L., HomcoRyan, C., and McKeith, F. W. (2003) Enhancement solution effects on shelf life, colour and sensory characteristics of pork chops during display. J. Food Qual. 26, 271-283.

15. John, L., Cornforth, D., Carpenter, C. E., Sorheim, O., Pettee, B. C., and Whittier, D. K. (2005) Color and thiobarbituric acid values of cooked top sirloin steaks packaged in modified atmosphere of $80 \%$ oxygen, or $0.4 \%$ carbon monoxide, or vacuum. Meat Sci. 69, 441-449.

16. Kim, Y. H., Huff-Lonergan, E., Sebranek, J. G., and Lonergan, S. M. (2010) High-oxygen modified atmosphere packaging system induces lipid and myoglobin oxidation and protein polymerization. Meat Sci. 85, 759-767.

17. Kim, Y. H., Keeton, J. T., Smith, S. B., Maxim, J. E., Yang, H. S., and Savell, J. W. (2009) Evaluation of antioxidant capacity and color stability of calcium lactate enhancement on fresh beef under highly oxidizing condition. Food Chem. 115, 272-278.

18. Knock, R. C., Seyfert, M., Hunt, M. C., Dikeman, M. E., Mancini, R. A., and Unruh, J. A. (2006) Effects of potassium lactate, sodium chloride, sodium tripolyphosphate, and sodium acetate on colour, colour stability, and oxidative properties of injection-enhanced beef rib steaks. Meat Sci. 74, 312-318.

19. Kohsaka, K. (1975) Freshness preservation of food and measurement. Food Ind. 18, 105-111. 
20. Lawrence, T. E., Dikeman, M. E., Hunt, M. C., Kastner, C.L., and Johnson, D. E. (2003) Effects of calcium salts on beef longissimus quality. Meat Sci. 64, 299-308.

21. Lee, B. J., Hendricks, D. G., and Cornforth, D. P. (1999) A comparison of carnosine and ascorbic acid on color and lipid stability in a ground beef patties model system. Meat Sci. 51, 245-253.

22. Lin, K. W. and Chuang, C. H. (1999) Effects of dipping of raw meat materials on the physicochemical and shelf-life of low-fat Chinese-style sausage. Food Sci. (Taiwan) 26, 583595.

23. Lin, K. W. and Lin, S. H. (2002) Effects of sodium lactate and trisodium phosphate on the physicochemical properties and shelf-life of low-fat Chinese-style sausage. Meat Sci. 60, 147-154.

24. Livingston, M., Brewer, M. S., Killifer, J., Bidner, B., and McKeith, F. W. (2004) Shelf life characteristics of enhanced modified atmosphere packaged pork. Meat Sci. 68, 115-122.

25. Maca, J. V., Miller, R. K., and Acuff, G. R. (1997) Microbiological, sensory, and chemical characteristics of vacuum packaged ground beef patties treated with salts of organic acids. J. Food Sci. 62, 591-596.

26. Maca, J. V., Miller, R. K., Bigner, M. E., Lucia, L. M., and Acuff, G. R. (1999) Sodium lactate and storage temperature effects on shelf life of vacuum packaged beef top rounds. Meat Sci. 53, 23-29.

27. Mancini, R. A. and Hunt, M. C. (2005) Current research in meat color: review. Meat Sci. 71, 100-121.

28. Mancini, R. A., Hunt, M. C., Hachmeister, K. A., Seyfert, M., Kropf, D. H., Johnson, D. E., Cusick, S., and Morrow, C. (2005) The utility of lactate and rosemary in beef enhancement solutions: effects on longissimus color changes during display. J. Muscle Foods 16, 27-36.

29. McMillin, K. W. (2008) Where is MAP Going? A review and future potential of modified atmosphere packaging for meat: review. Meat Sci. 80, 43-65.

30. Muhlisin, Kang, S. M., Choi, W. H., Lee, K. T., Cheong, S. H., and Lee, S. K. (2010) Combined effects of modified atmosphere packaging and organic acid salts (sodium acetate and calcium lactate) on the quality and shelf-life of hanwoo ground beef patties. Korean J. Food Sci. Ani. Resour. 30, 685-694.

31. Nam, K. C., Jo, C., and Lee, M. (2010) Meat products and consumption culture in the east. Meat Sci. 86, 95-102.

32. Okayama, T., Muguruma, M., Murakami, S., and Yamada, H. (1995) Studies on modified atmosphere packaging of thin sliced beef. 1. Effect of two modified atmosphere packaging systems on $\mathrm{pH}$ value, microbial-growth, metmyoglobin formation and lipid oxidation of thin sliced beef. J. Jpn. Society Food Sci. Technol. 42, 498-504.

33. Renerre, M. and Labadie, J. (1993) Fresh red meat packaging and meat quality. Proceed. 39th Int. Cong. Meat Sci. Technol., Calgary, Canada, pp. 361-387.

34. Rubio, B., Martinez, B., Gonzalez-Fernandez, C., GarciaCachan, M, D., Rovira, J., and Jaime, I. (2007) Effect of modified atmosphere packaging on the microbiological and sensory quality on a dry cured beef product: "Cecina de león". Meat
Sci. 75, 515-522.

35. Sallam, K. I. and Samejima, K. (2004) Microbiological and chemical quality of ground beef treated with sodium lactate and sodium chloride during refrigerated storage. LWT-Food Sci. Technol. 37, 865-871.

36. Sallam, K. I. (2007) Antimicrobial and antioxidant effects of sodium acetate, sodium lactate, and sodium citrate in refrigerated sliced salmon. J. Food Cont. 18, 566-575.

37. Sanchez-Escalante, A., Djenane, D., Torrescano, G., Beltran, A., and Roncales, P. (2001) The effects of ascorbic acid, taurine, carnosine and rosemary powder on colour and lipid stability of beef patties packaged in modified atmosphere. Meat Sci. 58, 421-429.

38. Schirmer, B. C., Heiberg, R., Eie, T., Møretrø, T., and Carlehøg, M. (2009) A novel packaging methods with dissolving $\mathrm{CO}_{2}$ headspace combined with organic acids prolongs the shelf-life of fresh salmon. Int. J. Food Microbiol. 133, 154160.

39. Schirmer, B. C. and Langsrud, S. (2010) A dissolving $\mathrm{CO}_{2}$ headspace combined with organic acids prolongs the shelflife of fresh pork. Meat Sci. 85, 280-284.

40. Sebranek, J. G. and Bacus, J. N. (2007) Cured meat products without direct addition of nitrate or nitrite: what are the issues? Meat Sci. 77, 136-147.

41. Sebranek, J. G. and Houser, T. A. (2006) Modified atmosphere packaging. In: advance technology for meat processing. Nollet, L. M. L. and Toldra, F. (eds) Taylor \& Francis Group, Florida, pp. 419-447.

42. Seyfert, M., Hunt, M. C., Mancini, R. A., Kropf, D. H., and Stroda, S. L. (2004) Internal premature browning in cooked steaks from enhanced beef round muscle packaged in highoxygen and ultra-low oxygen modified atmosphere. J. Food Sci. 69, 142-146.

43. Shelef, L. A., Mohammed, S., Tan, W., and Webber, M. L. (1997) Rapid optical measurements of microbial contamination in raw ground beef and effects of citrate and lactate. $J$. Food Prot. 60, 673-676.

44. Shelef, L. A. and Potluri, V. (1995) Behaviour of foodborne pathogens in cooked liver sausage-containing lactates. Food Microbiol. 12, 221-227.

45. Shrestha, S. and Min, Z. (2006) Effect of lactic acid pretreatment on the quality of fresh pork packed in modified atmosphere. J. Food Eng. 72, 254-260.

46. Simpson, R., Avecedo, C., and Almonacid, S. (2009) Mass transfer of $\mathrm{CO}_{2}$ in MAP system: Advances for non-respiring foods. J. Food Eng. 92, 233-239.

47. Sinhuber, R. O. and Yu, T. C. (1977) The 2-thiobarbituric acid reaction, an objective measure of the oxidative deterioration occurring in fat and oil. J. Jpn. Soc. Fish Sci. 26, 259267.

48. Skibsted, L. H., Mikkelsen, A., and Bertelsen, G. (1998) Lipid-derived off-flavours in meat. In: flavor of meat, meat products and seafoods. Shahidi, F. (ed), Blackie Academic \& Professional, London, pp. 217-248.

49. Smith, J. P., Ramaswamy, H. S., and Simpson, B. K. (1990) Development in food packaging technology. Part II. Storage 
aspects. Trends Food Sci. Technol. 5, 111-118.

50. SPSS (2005) SPSS 14.0 for Windows Evaluation Version, SPSS Inc., Illinois, USA.

51. Viana, E. S., Gomide, L. A. M., and Vanetti, M. C. D. (2005) Effect of modified atmospheres on microbiological, color and sensory properties of refrigerated pork. Meat Sci. 71, 696-705.

52. Velugoti, P. R., Rajagopal, L., Juneja, V., and Thippareddi, H. (2007) Use of calcium, potassium, and sodium lactates to control germination and outgrowth of Clostridium perfringens spores during chilling of injected pork. Food Microbiol. 24, 687-694.

53. Wimpfheimer, L., Altman, N. S., and Hotchkiss, J. H. (1990)
Growth of Listeria monocytogenes Scott A, serotype 4 and competitive spoilage organism in raw chicken packaged under modified atmospheres and in air. Int. J. Food Microbiol. 11, 205-214.

54. Yi, Y. H. and Chen, T. C. (2003) Prediction of lean to fat tissue ration of pork belly by specific gravity. J. Food Eng. 58, 295-297.

55. Zakrys, P. I., Hogan, S. A., O’Sullivan, M. G., Allen, P., and Kerry, J. P. (2008) Effects of oxygen concentration on the sensory evaluation and quality indicators of beef muscle packed under modified atmosphere. Meat Sci. 79, 648-655.

(Received 2010.12.6/Revised 1st 2011.9.17, 2nd 2011.9.26/ Accepted 2011.9.29) 